\title{
Considerations to Planning Orthognathic Surgery in Different Regions of Saudi and the Middle East
}

\author{
Mazen Almasri, ${ }^{1, *}$, Sara M. Bukhari ${ }^{2}$ \\ ${ }^{1}$ Assistant professor, Umm Alqura University, Oral Maxillofacial Surgery Department, Saudi Arabia \\ ${ }^{2}$ King Abdulaziz Medical City. Jeddah, Saudi Arabia \\ *Corresponding author: mazen_ajm@yahoo.com
}

Received December 13, 2013; Revised December 19, 2013; Accepted January 03, 2014

\begin{abstract}
Objectives: to properly plan orthongathic surgery and the fine beauty details in it, understanding different ethnic facial norms is necessary. In Saudi, investigating the existence of any facial variation has not been studied before, and hence we are investigating the existence of any variation of soft tissue profile (STP) among Saudi patients in the Southern region (SSA) when compared to the middle region of Saudi (MSA) that require considerations when planning facial surgeries. Material and methods: A retrospective chart review from August 2010 to June 2012 of Patients with class I skeletal relation, no history of orthognathic facial deformity, syndromes nor cleft lip and palate were included in the study. 93 patients with an age ranged from 15-33 years old were compared to a similar group in the MSA. Clinical pictures and lateral cephalometric radiographs superimpositions were used to examine the data and tabulate the results. Results: it has been shown that although similarities exist between the STP of patients in the SSA and MSA, some characters were found significantly different in SSA group such as females showing more microgenic tendency, more acute nasolabial angle and larger interlabial gap than MSA females. While SSA males on as well showed more microgenia and longer face tendency than MSA males. Conclusion: When planning orthognathic surgery for SSA patients, careful consideration for lower facial third character is necessary as tendency toward microgenia in the patient population sounds like a common feature in males and females.
\end{abstract}

\section{Keywords: orthognathic, profile, treatment plan}

Cite This Article: Mazen Almasri, and Sara M. Bukhari, "Considerations to Planning Orthognathic Surgery in Different Regions of Saudi and the Middle East." American Journal of Public Health Research 2, no. 1 (2014): 6-9. doi: 10.12691/ajphr-2-1-2.

\section{Introduction}

Planning orthognathic surgery is always the key to successful outcomes. It is well known that family and ethnic variation do exist and is highly considered when planning facial surgeries in general including orthognathics as the skeletal movement has a direct effect on the soft tissue final results accordingly $[1,2,3,4]$. Understanding the common facial trait and the possible effects of jaw skeletal movement and soft tissue changes will help the clinicians to estimate the plans needed [5]. In Saudi Arabia, investigations have been concerned with developing norms for adults regarding hard tissue cephalometric measurements $[6,7,8,9]$. Nevertheless, Caucasian norms were still referred to when Saudi patients were being treated. For this reason, Aldrees (2011) performed a meta-analysis of relevant studies discussed skeletal and dental norms for Saudis and was clear that the substantial lacking in the soft tissue profile (STP) analysis was still an issue [10]. Since the fact that STP significantly affects the treatment plan process, attention has been diverted to this issue and several studies have been conducted in the middle region of Saudi Arabia
(MSA) concerning this subject [10,11,12,13]. However, regional variations were not studied yet in the kingdom and hence, our study is investigating the existence of such variation through a pilot study by comparing STP of patients from the Southern region of Saudi (SSA) to patients from the middle region of Saudi (MSA) as another additive step toward understanding orthongathic surgery planning in Saudi patients of different regions [14].

\section{Material and Methods}

After getting the ethical protocol approval following the Helsinki's declaration guide and declaring that no conflict of interest exist, a chart review between August 2010 and June 2012 was conducted to review the clinical pictures and lateral cephalometric radiographs of southern Saudi Patients aged from 15-33 years, at Aseer central hospital (King Khalid University Maxillofacial research and Health Center). Cases of class I skeletal relationship, normal overjet and overbite, no skeletal vertical or transverse abnormalities, no history of facial surgery, no syndromes or cleft lip and palate where included (in addition to following Helsinki's declaration for patient inclusion). A total of 93 cases were included to analyze 
their clinical images and radiographic records. Out of the 93 images, 65 males and 28 females were identified and traced using CLINIVIEW ${ }^{\mathrm{TM}}$ software. Next, all the pertinent hard and soft tissue measurements were tabulated accordingly. Next, statistical analysis was performed using SPSS program (version 18 SPSS) and independent $\mathrm{T}$ tests for both genders were used for comparing the tabulated data between genders and to Albarakti’s STP results from the MSA [14,15].

\section{Results}

\begin{tabular}{|c|c|c|c|c|c|c|c|c|}
\hline Variables & Measurements & $\begin{array}{c}\text { Female } \\
\text { Mean }\end{array}$ & $\begin{array}{c}\text { Female } \\
\text { SD }\end{array}$ & $\begin{array}{l}\text { Male } \\
\text { Mean }\end{array}$ & $\begin{array}{c}\text { Male } \\
\text { SD }\end{array}$ & T-Value & P-Value & Interpretation \\
\hline \multicolumn{9}{|l|}{ Facial form: } \\
\hline $\begin{array}{l}\text { Facial convexity } \\
\text { angle (dg) }\end{array}$ & G-Sn-Pg' & 15.61 & 5.21 & 17.06 & 6.17 & 1.09 & $0.279 \mathrm{NS}$ & \\
\hline $\begin{array}{l}\text { Maxillary } \\
\text { prognathism } \\
(\mathrm{mm})\end{array}$ & G-Sn(HP) & 6.67 & 5.12 & 7.59 & 4.18 & 0.91 & 0.366 NS & \\
\hline $\begin{array}{l}\text { Mandibular } \\
\text { prognathism } \\
(\mathrm{mm})\end{array}$ & G-Pg'(HP) & -1.74 & 9.23 & -2.14 & 8.28 & -0.2 & 0.845 NS & \\
\hline $\begin{array}{l}\text { Vertical height } \\
\text { ratio }\end{array}$ & G-Sn/Sn-Me' & 1.1 & 0.31 & 0.98 & 0.12 & -2.8 & $0.006^{*}$ & \multirow[t]{2}{*}{$\begin{array}{l}\text { Males have disproportionally } \\
\text { larger lower third of the face. }\end{array}$} \\
\hline $\begin{array}{l}\text { Lower face-throat } \\
\text { angle (dg) }\end{array}$ & Sn-Gn'-C & 97.49 & 20.71 & 105.36 & 21.08 & 1.67 & 0.100 NS & \\
\hline $\begin{array}{l}\text { Lower vertical } \\
\text { height-depth ratio } \\
\text { Lip position \& }\end{array}$ & Sn-Gn'/C-Gn' & 1.36 & 0.25 & 1.58 & 0.37 & 2.85 & $0.005^{*}$ & $\begin{array}{l}\text { Males have shorter neck and } \\
\text { microgenia. }\end{array}$ \\
\hline $\begin{array}{l}\text { form: } \\
\text { Nasolabial angle } \\
\text { (dg) }\end{array}$ & Cm-Sn-Ls & 100.68 & 12.66 & 105.54 & 11.43 & 1.82 & 0.072 NS & \\
\hline $\begin{array}{l}\text { Upper lip } \\
\text { protrusion (mm) }\end{array}$ & Ls to (Sn-Pg') & 4.05 & 2.17 & 4.15 & 1.63 & 0.25 & 0.802 NS & \\
\hline $\begin{array}{l}\text { Lower lip } \\
\text { protrusion (mm) }\end{array}$ & Li to (Sn-Pg') & 4.11 & 2.47 & 3.78 & 2.43 & -0.59 & $0.556 \mathrm{NS}$ & \\
\hline $\begin{array}{l}\text { Mentolabial } \\
\text { sulcus (mm) }\end{array}$ & Si to (Li-Pg') & 4.82 & 1.79 & 5.45 & 2.01 & 1.42 & 0.158 NS & \\
\hline $\begin{array}{l}\text { Vertical lip-chin } \\
\text { ratio }\end{array}$ & $\begin{array}{l}\text { Sn-Stms/Stmi- } \\
\text { Me' }\end{array}$ & 0.52 & 0.6 & 0.41 & 0.07 & -1.46 & $0.148 \mathrm{NS}$ & \\
\hline $\begin{array}{l}\text { Maxillary incisor } \\
\text { exposure (mm) }\end{array}$ & Stms-1 & 3.99 & 2.6 & 4.21 & 7.37 & 0.15 & 0.878 NS & \\
\hline $\begin{array}{l}\text { Interlabial gap } \\
(\mathrm{mm})\end{array}$ & $\begin{array}{l}\text { Stms-Stmi } \\
\text { (HP) }\end{array}$ & 3.84 & 3.38 & 3.42 & 3.56 & -0.53 & $\begin{array}{l}0.600 \\
\text { NS }\end{array}$ & \\
\hline
\end{tabular}

*significant. NS - not significant. HP - horizontal reference plane, S - sella, N- Nasion, G - glabella, Cm - columella point, Sn - subnasale, Ls - labrale superius, Stms- stomion superius, Stmi - stomion inferius, Li - labrale inferius, Si - mentolabial sulcus, Pg - soft tissue pogonion, Gn’ - soft tissue gnathion, Me' - Soft tissue menton, $\mathrm{C}$ - Cervical point

Table 2. a comparison of the soft tissue cephalometric measurements between MSA females and SSA females (Legan and Burstone analysis)

\begin{tabular}{|c|c|c|c|c|c|c|c|c|}
\hline Variables & Measurements & $\begin{array}{l}\text { MSA } \\
\text { Mean }\end{array}$ & $\begin{array}{c}\text { MSA } \\
\text { SD }\end{array}$ & $\begin{array}{c}\text { SSA } \\
\text { Mean } \\
\end{array}$ & $\begin{array}{c}\text { SSA } \\
\text { SD }\end{array}$ & T-Value & P-Value & Interpretation \\
\hline *Facial form: & & & & & & & & \multirow{8}{*}{$\begin{array}{l}\text { SSA females have shorter neck and } \\
\text { microgenia. } \\
\text { - More upwardly sloping position } \\
\text { of columella of MSA females. } \\
\text { - Slightly more protrusive upper lip } \\
\text { of SSA females. } \\
\text { - More proclined upper anterior } \\
\text { teeth of SSA females. }\end{array}$} \\
\hline $\begin{array}{l}\text { Facial convexity angle } \\
\text { (dg) }\end{array}$ & G-Sn-Pg' & 15.53 & 4.92 & 15.61 & 5.21 & 0.06 & 0.952 NS & \\
\hline $\begin{array}{l}\text { Maxillary } \\
\text { prognathism (mm) }\end{array}$ & G-Sn(HP) & 6.77 & 3.63 & 6.67 & 5.12 & -0.09 & 0.932 NS & \\
\hline $\begin{array}{l}\text { Mandibular } \\
\text { prognathism (mm) }\end{array}$ & G-Pg'(HP) & -0.49 & 6.62 & -1.74 & 9.23 & -0.59 & $0.559 \mathrm{NS}$ & \\
\hline Vertical height ratio & $\mathrm{G}-\mathrm{Sn} / \mathrm{Sn}-\mathrm{Me}$ & 1.02 & 0.10 & 1.10 & 0.31 & 1.34 & 0.185 NS & \\
\hline $\begin{array}{l}\text { Lower face-throat } \\
\text { angle (dg) }\end{array}$ & Sn-Gn'-C & 101.12 & 7.31 & 97.49 & 20.71 & -0.88 & $0.386 \mathrm{NS}$ & \\
\hline $\begin{array}{l}\text { Lower vertical } \\
\text { height-depth ratio }\end{array}$ & Sn-Gn'/C-Gn' & 1.09 & 0.17 & 1.36 & 0.25 & 4.84 & $<0.0001^{*}$ & \\
\hline $\begin{array}{l}\text { *Lip position \& } \\
\text { form: } \\
\begin{array}{l}\text { Nasolabial angle } \\
\text { (dg) }\end{array}\end{array}$ & Cm-Sn-Ls & 109.68 & 11.4 & 100.68 & 12.66 & -2.85 & $0.006^{*}$ & \\
\hline $\begin{array}{l}\text { Upper lip protrusion } \\
(\mathrm{mm})\end{array}$ & Ls to (Sn-Pg') & 3.39 & 1.61 & 4.05 & 2.17 & 132 & 0.192 NS & \multirow{5}{*}{$\begin{array}{l}\text { More flared lower incisors of SSA } \\
\text { females. }\end{array}$} \\
\hline $\begin{array}{l}\text { Lower lip protrusion } \\
(\mathrm{mm})\end{array}$ & Li to (Sn-Pg') & 2.84 & 1.91 & 4.11 & 2.47 & 2.20 & $0.032 *$ & \\
\hline $\begin{array}{l}\text { Mentolabial sulcus } \\
(\mathrm{mm})\end{array}$ & Si to (Li-Pg') & 4.32 & 1.32 & 4.82 & 1.79 & 1.22 & $0.299 \mathrm{NS}$ & \\
\hline Vertical lip-chin ratio & $\begin{array}{l}\text { Sn-Stms/Stmi- } \\
\text { Me' }\end{array}$ & 0.46 & 0.05 & 0.52 & 0.60 & 0.53 & $0.602 \mathrm{NS}$ & \\
\hline $\begin{array}{l}\text { Maxillary incisor } \\
\text { exposure (mm) }\end{array}$ & Stms-1 & 3.37 & 1.38 & 3.99 & 3.38 & 1.15 & $0.25 \mathrm{NS}$ & \\
\hline Interlabial gap (mm) & Stms-Stmi (HP) & 1.73 & 0.58 & 3.84 & 3.38 & 3.26 & $0.003^{*}$ & $\begin{array}{l}\text { - Vertical maxillary excess } \\
\text { - shorter upper lip of SSA females. }\end{array}$ \\
\hline
\end{tabular}

*significant. NS - not significant. HP - horizontal reference plane, S - sella, N- Nasion, G - glabella, Cm - columella point, Sn - subnasale, Ls - labrale superius, Stms- stomion superius, Stmi - stomion inferius, Li - labrale inferius, Si - mentolabial sulcus, Pg - soft tissue pogonion, Gn'- soft tissue gnathion, Me' - Soft tissue menton, $\mathrm{C}$ - Cervical point 
Table 3. a comparison of the soft tissue cephalometric measurements between MSA males and SSA males (Legan and Burstone analysis)

\begin{tabular}{|c|c|c|c|c|c|c|c|c|}
\hline Variables & Measurements & $\begin{array}{l}\text { MSA } \\
\text { Mean }\end{array}$ & $\begin{array}{c}\text { MSA } \\
\text { SD }\end{array}$ & $\begin{array}{c}\text { SSA } \\
\text { Mean }\end{array}$ & $\begin{array}{c}\text { SSA } \\
\text { SD } \\
\end{array}$ & T-Value & P-Value & Interpretation \\
\hline \multicolumn{9}{|l|}{ *Facial form: } \\
\hline $\begin{array}{l}\text { Facial convexity } \\
\text { angle (dg) }\end{array}$ & G-Sn-Pg' & 14.85 & 4.41 & 17.06 & 6.17 & 1.79 & $0.077 \mathrm{NS}$ & \multirow{13}{*}{$\begin{array}{l}\text { SSA males have shorter neck } \\
\text { and microgenia. }\end{array}$} \\
\hline $\begin{array}{l}\text { Maxillary } \\
\text { prognathism (mm) }\end{array}$ & G-Sn(HP) & 6.21 & 4.83 & 7.59 & 4.18 & 1.44 & $0.154 \mathrm{NS}$ & \\
\hline $\begin{array}{l}\text { Mandibular } \\
\text { prognathism (mm) }\end{array}$ & G-Pg'(HP) & -2.14 & 7.70 & -2.14 & 8.28 & 0.00 & $\begin{array}{l}>0.999 \\
\text { NS }\end{array}$ & \\
\hline Vertical height ratio & G-Sn/Sn-Me' & 1.00 & 0.09 & 0.98 & 0.12 & -0.82 & $0.413 \mathrm{NS}$ & \\
\hline $\begin{array}{l}\text { Lower face-throat } \\
\text { angle (dg) }\end{array}$ & Sn-Gn'-C & 103.89 & 9.05 & 105.36 & 21.08 & 0.48 & $0.634 \mathrm{NS}$ & \\
\hline $\begin{array}{l}\text { Lower vertical } \\
\text { height-depth ratio } \\
\text { *Lip position \& }\end{array}$ & Sn-Gn'/C-Gn' & 1.20 & 0.23 & 1.58 & 0.37 & 5.247 & $<0.0001^{*}$ & \\
\hline $\begin{array}{l}\text { form: } \\
\text { Nasolabial angle } \\
\text { (dg) }\end{array}$ & Cm-Sn-Ls & 102.85 & 10.68 & 105.54 & 11.43 & 1.10 & $0.274 \mathrm{NS}$ & \\
\hline $\begin{array}{l}\text { Upper lip } \\
\text { protrusion (mm) }\end{array}$ & Ls to (Sn-Pg') & 4.24 & 1.53 & 4.15 & 1.63 & -0.26 & $0.797 \mathrm{NS}$ & \\
\hline $\begin{array}{l}\text { Lower lip } \\
\text { protrusion (mm) }\end{array}$ & Li to (Sn-Pg') & 3.63 & 2.22 & 3.78 & 2.43 & 0.29 & $0.772 \mathrm{NS}$ & \\
\hline $\begin{array}{l}\text { Mentolabial sulcus } \\
(\mathrm{mm})\end{array}$ & Si to (Li-Pg') & 4.85 & 1.17 & 5.45 & 2.01 & 1.54 & $0.127 \mathrm{Ns}$ & \\
\hline $\begin{array}{l}\text { Vertical lip-chin } \\
\text { ratio }\end{array}$ & $\begin{array}{l}\text { Sn-Stms/Stmi- } \\
\text { Me' }\end{array}$ & 0.44 & 0.06 & 0.41 & 0.07 & -2.05 & $0.043^{*}$ & \\
\hline $\begin{array}{l}\text { Maxillary incisor } \\
\text { exposure (mm) }\end{array}$ & Stms-1 & 3.18 & 2.48 & 4.21 & 7.37 & 1.01 & $0.314 \mathrm{NS}$ & \\
\hline $\begin{array}{l}\text { Interlabial gap } \\
(\mathrm{mm})\end{array}$ & Stms-Stmi (HP) & 2.69 & 1.24 & 3.42 & 3.56 & 1.48 & $0.144 \mathrm{NS}$ & \\
\hline
\end{tabular}

*significant. NS - not significant. HP - horizontal reference plane, S - sella, N- Nasion, G - glabella, Cm - columella point, Sn - subnasale, Ls - labrale superius, Stms- stomion superius, Stmi - stomion inferius, Li - labrale inferius, Si - mentolabial sulcus, Pg - soft tissue pogonion, Gn’- soft tissue gnathion, Me' - Soft tissue menton, $\mathrm{C}$ - Cervical point

Independent $\mathrm{T}$ Tests were used to compare the pertinent variables with equal variance otherwise Welch's T-Test was used and results presented in Table 1, Table 2 and Table 3. Comparing the facial form in males and females in the SSA region (Table 1) presented males having significantly larger lower facial third and microgenic tendency while all the other variables associated with lip position and form showed no significant gender difference. (Power < 0.05, Confidence interval $(\mathrm{CI})=95 \%$ )

When comparing SSA females to MSAs' (Table 2), the SSA females' facial form was found to have significantly more acute nasolabial angle and larger interlabial gap, more protrusive lower lip and microgenic tendency than females of MSA. While comparing SSA males to MSAs' (Table 3) presented SSA males having significantly longer lower face and microgenic tendency than MSA males.

\section{Discussion}

Oral Maxillofacial surgeon, facial cosmetic / reconstructive surgeons, and orthodontists frequently have questions in mind about case treatment planning, such as " can this face take more protrusion / retrusion? " or " can this lady take more smaller chin than what she has? “ $[15,16]$. The answer to such question can have a positive or negative number with variable degrees according to the patient general facial character and ethnic background. Therefore, as long as no clear numbers are established for variable facial characters in different facial traits including Saudis, the magnitude of such movement can not be clearly identified and still will has a subjective way of measurement based on surgeons own experience and definition of beauty. Hence, a Pubmed literature review revealed several studies conducted to investigate the STP in the population of Saudi Arabia. In the MSA, Aljasser [16] presented significant differences in the STP between
Saudi and Caucasian populations, while Hashim [17] proved the same when compared a sample of Saudi females to different ethnic groups (American black and white females and a third group of British females). The significant difference that was found in the STP of different groups proves that Caucasian Americans norms can't be relied on in the treatment planning of orthognathic surgical cases of Saudi population. Furthermore, AlBarakati et al compared a sample of Saudi adults to Anatolian Turkish, Japanese, Holdaway reported values and a European-American Legan and Burstone's values $[17,18,19,20,21]$. The results found significantly different STP values of Saudi population compared to the other facial ethnics mentioned. The aforementioned, only confirms that referring to the Caucasian norms or others in treating Saudi patients is unreliable and that a solid base line of cephalometric criteria for Saudi population deemed to be necessary to be studied and considered for all regions of Saudi Arabia [15,16].

The current pilot study compared STP measurements of a sample of Saudi subjects in the SSA to another sample in MSA that was presented in Albarakati's study based on Legan and Burstone analysis [Figure 1] in an attempt to investigate regional variation in different areas of Saudi. The sample in our study included the clinical and cephalometric superimposition measurements of 93 adults, which is a number slightly exceeding the sample size in most of the studies done in MSA [11-17].

In general, the findings of SSA adults were in agreement with MSA adults in regard to the tendency of class I convex facial profile and the bilabial protrusion, even though the SSA sample exhibited more tendency toward class II facial profile that is likely to be due to mandibular retrognathism, microgenia, and shorter neck when compared to MSA sample. In addition, SSA females showed more acute nasolabial angle, larger interlabial gap, and more protrusive lower lip than MSAs'. The 
aforementioned suggests that STP generally is very comparable between the two groups except of few measurements toward the lower facial third criteria. Hence, such regional variation needs to be considered, investigated, and discussed thoroughly with patients in further depth to establish a solid guideline when planning facial surgeries. The author still advice a case-by-case treatment plan, thourough discussion, interspecialty consultations and expert clinical judgment and perception of beauty to be the cornerstones in designing the best orthognathic surgical maneuver.

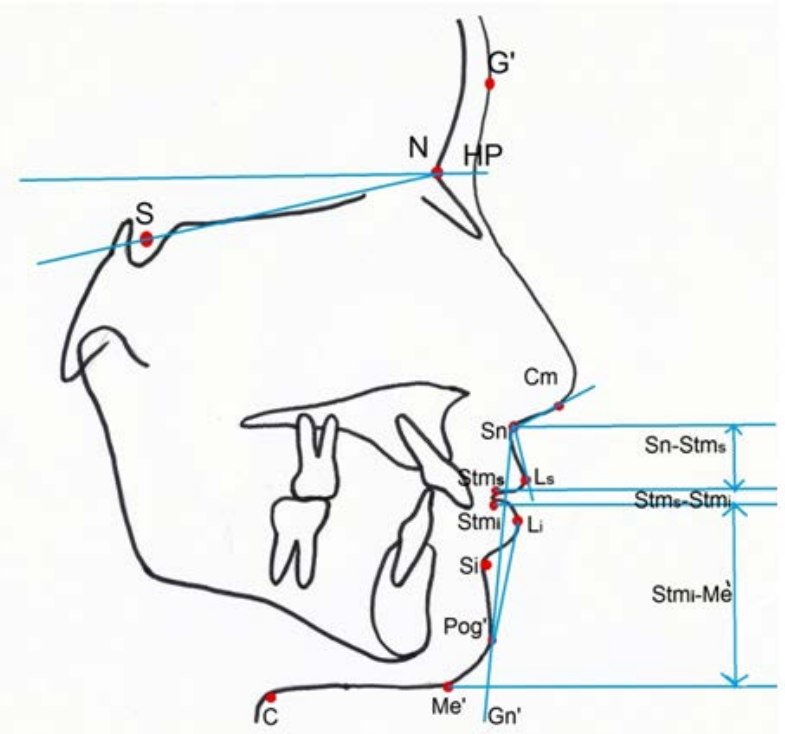

Figure 1. lip form and position soft tissue analysis. (A sample of profile lower face analysis); nasolabial angle (Cm-Sn-Ls), mentolabial sulcus depth (Si to Li-Pog'), maxillary incisor exposure (Stms-1). b) Upper lip protrusion (Ls to Sn-Pg'), lower lip protrusion (Li to Sn-Pog'), vertical lip-chinratio (Sn-Stms / Stmi-Me'), interlabial gap (Stms-Stmi).

\section{Acknowledgement}

The authors would like to thank the Maxillofacial research center at the Faulty of Dentistry in King Khalid University for facilitating our work. In addition, a special gratitude to Dr Fawaz Baig (Oral Maxillofacial Surgery Department), Prof. Adel Mostafa (Prosthodontic department) and Dr Bandar Alshehri (pediatric dentistry department) for their help and support.

\section{References}

[1] Legan, H., Burstone, C.J, "Soft tissue cephalometric analysis for orthognathic surgery”. J. Oral Surg. 38, 1980, pp. 744-751.
[2] Holdaway, R., "A soft-tissue cephalometric analysis and its use in orthodontic treatment planning. Part I”. Am. J. Orthod. 84 (1), 1983, pp. 1-2.

[3] Bergman, R., "Cephalometric soft tissue facial analysis”. Am. J. Orthod. Dentofacial Orthop. 116 (4), 1999, pp. 373-89.

[4] Subtelny, J., “A longitudinal study of soft tissue facial structures and their profile characteristics, defined in relation to underlying skeletal structures.” Am. J. Orthod. 45, 1959, pp. 481-507.

[5] Hwang, H., Kim, W.S., McNamara Jr, "Ethnic differences in the soft tissue profile of Korean and European-American adults with normal occlusions and well-balanced faces”. Angle Orthod. 72 (1), 2002, pp. 72-80.

[6] Lew, K., Ho, K.K., Keng, S.B., Ho, K.H, "Soft-tissue cephalometric norms in Chinese adults with esthetic facial profiles.” J. Oral Maxillofac. Surg. 50, 1992, pp. 1184-1189.

[7] Scavone, H., Trevisan, H., Garib, D.G., Ferreira, F.V, "Facial profile evaluation in Japanese-Brazilian adults with normal occlusions and well-balanced faces.” Am. J. Orthod. Dentofacial Orthop. 129, 2006, pp. 721-25.

[8] Al-Gunaid, T., Yamada, K., Yamaki, M., Saitod, I, "Soft-tissue cephalometric norms in Yemeni men.” Am. J. Orthod. Dentofacial Orthop. 132, 2007, pp. 576.

[9] AlBarakati, S., Bindayel N.A., "Holdaway soft tissue cephalometric standards for Saudi adults.” J. King Saud Univ.dental Sci. 3, 2012, pp. 27-32.

[10] Baidas, L., AlBarakati, S.A., "Comparative Orthognathic Cephalometric Study Among Saudi, African-American and Japanese Adults: Hard Tissue Measurements.” J. King Saud Univ.dental Sci. 22 (1), 2011, pp. 15-24.

[11] AlBarakati, S., "Soft tissue facial profile of adult Saudis." Saudi Med J. 32 (9), 2011, pp. 836-842.

[12] AlBarakati, S., Baidas L.F., "Orthognathic surgical norms for a sample of Saudi adults: Hard tissue measurements." Saudi Dent. J. 22, 2010, pp. 133-139.

[13] Al-Barakati, S., Talic, N.F, "Cephalometric norms for Saudi sample using McNamara analysis.” Saudi Dent. J. 19, 2007, pp. 139-145.

[14] Aldrees, A., "Lateral cephalometric norms for Saudi adults: A meta-analysis." Saudi Dent. J. 23, 2011, pp. 3-7.

[15] Al-Jasser, N., "Facial esthetics in a selected Saudi population." Saudi Med. J. 24 (9), 2003. pp. 1000-1005.

[16] Hashim, H., "A cephalometric study of soft tissue relationship among Saudi female dental students.” Saudi Dent. J. 15 (1), 2003, pp. 41-44.

[17] Hashim, H., AlBarakati, S.F, "Cephalometric soft tissue profile analysis between two different ethnic groups: a comparative study.” J. Contemp. Dent. Pract. 4 (2), 2003, pp. 60-73.

[18] Abdul-Qadir, M., Al-Dawoody, A.D., Agha, N.F, "Evaluation of Holdaway Soft Tissue Analysis for Iraqi Adults with Class I Normal Occlusion.” Al-Rafidain Dent J, 8 (2), 2008, pp. 231-237.

[19] Abu-Tayyem, H., Alshamsi, A.H., Hafez, S, Mohie Eldin E, "Cephalometric norms for a sample of Emirates adults." Open Journal of Stomatology. 1 (3), 2010, pp. 75-83.

[20] Uysal, T., Baysal, A., Yagci, A., Sigler, L.M., McNamara, J.A, "Ethnic differences in the soft tissue profiles of Turkish and European-American young adults with normal occlusions and well-balanced faces.” Eur. J. Orthod. 34 (3), 2012, pp. 296-301.

[21] Shalhoub, H., Sarhan, O.A., Shaikh, H.S., "Adult cephalometric norms for Saudi Arabians with a comparison of values for Saudi and North American Caucasians.” Br. J. Orthod. 14, 1987, pp. 273-279. 